\title{
Architecture_MPS
}

\section{Re-Picturing the "Post-Fordist" Motor City: Commissioned Street Art in Downtown Detroit}

Brian Brown ${ }^{1}$

How to cite: Brown, B. 'Re-Picturing the "Post-Fordist" Motor City: Commissioned Street Art in Downtown Detroit.' Architecture_MPS, 2017, 12(1): 1. DOI: https://doi.org/10.14324/111.444.amps.2017v12i1.001.

Published: 01 September 2017

\section{Peer Review:}

This article has been peer reviewed through the journal's standard double blind peer-review, where both the reviewers and authors are anonymised during review.

\section{Copyright:}

(C) 2017, The Author(s). This is an Open Access article distributed under the terms of the Creative Commons Attribution License (CC-BY) 4.0 https://creativecommons.org/licenses/by/4.0/, which permits unrestricted use, distribution and reproduction in any medium, provided the original author and source are credited • DOI: https://doi.org/10.14324/111.444.amps.2017v12i1.001.

\section{Open Access:}

Architecture_MPS is a peer-reviewed open access journal.

\footnotetext{
${ }^{1}$ University of Windsor, Canada
} 


\title{
Title: Re-Picturing the "Post-Fordist" Motor City: Commissioned Street Art in Downtown Detroit
}

\section{Author: Brian Brown}

\section{Architecture_media_politics_society. vol.12, no. 1.}

September 2017

Affiliation: University of Windsor

\begin{abstract}
The primary goal of this paper is to examine the ways in which legal and sanctioned "street art" features as a prominent tool in the recent attempts to revitalize and rejuvenate one of the most storied and historically important cities in the world: Detroit, Michigan. It will do so first by examining some of the factors that hastened Detroit's decline from urban, industrial powerhouse to universally recognized symbol of post-industrial urban decay, and back again, to its present, albeit tenuous, status as celebrated emblem of urban regeneration. This is done so as to explain why the efforts to "save" Detroit in general are concentrated on such a small tract of land in the city's downtown core or "Central Business District" (CBD). Second, it will examine key planning documents jointly authored by stakeholders in the public and private sectors, that regard commissioned street art projects (such as Shepard Fairey's mural on the Quicken Loans Headquarters) as strategic aesthetic levers that attempt to author new narratives in the collective imaginary regarding the present and future of the troubled Motor City. Third, it draws on extensive field research undertaken in Detroit's CBD so as to argue that street art projects are important, but are also limited in their capacity to engage broader audiences/publics due to their being locked in situ. Fourth and finally, the role of technologies not traditionally associated with graffiti or street art (mobile digital cameras and social media) are regarded as pivotal to its reframing and current embrace by property developers and municipal officials. By leveraging the communicative capacities of ubiquitously connected mobile devices and their ability to capture and disseminate
\end{abstract}




\section{Amps}

digital photographs of street art, the reach of these photographs extends far beyond the limited physical confines of city streets, accessing publics accustomed to seeing vastly different photographs of Detroit. It is these digital and eminently social photographs, so often neglected in the academic literature, that are the visio-narrative devices being used to author the next chapter of Detroit's fabled history. 


\title{
Title: Re-Picturing the "Post-Fordist" Motor City: Commissioned Street Art in Downtown Detroit
}

\author{
Author: Brian Brown
}

Architecture_media_politics_society. vol. 12, no. 1 .

September 2017

\section{Introduction}

On September 10, 2016, The Toronto Star, Canada's largest daily newspaper, published a story identifying Detroit, Michigan, as "America's Great Comeback Story." The main headline's deck gushes, "Detroit is infused with art and abuzz with transformative change. Come experience the artist-led rebirth now and you'll find a city full of passionate people." The caption to its lead photograph claims that Detroit, "driven by art (not automobiles) ... is staging an impressive comeback." While the article is right to name "art" as an important driver of Detroit's fledgling attempt to defibrillate the heart of the "Motor City," this is a very particular and specific kind of art, unique to urban environments and this contemporary period. Indeed, "street art" is serviceable in its descriptive capacities, but not entirely accurate. The primary goal of this paper, then, is to examine the ways in which legal and sanctioned "street art" features as a prominent tool in the recent attempts to revitalize and rejuvenate one of the most storied and historically important cities in the world: Detroit, Michigan. It will do so first by examining some of the factors that hastened Detroit's decline from urban, industrial powerhouse to universally recognized symbol of post-industrial urban decay, and back again, to its present, albeit tenuous, status as celebrated emblem of urban regeneration. This is done so as to explain why the efforts to "save" Detroit in general are concentrated on such a small tract of land in the city's downtown core or "Central Business District" (CBD). Second, it will examine key planning documents jointly authored by stakeholders in the public and private sectors that name commissioned street art projects (such as Shepard Fairey's mural on the Quicken Loans Headquarters) as strategic aesthetic levers that attempt to author new narratives in the collective imaginary regarding the present and future of the troubled Motor City. ${ }^{2}$ Third, it draws on extensive field research undertaken in Detroit's CBD so as to argue that street art projects are important, but are also limited in their capacity to engage broader audiences/publics 


\section{Amps}

due to their being locked in situ. Fourth and finally, the role of technologies not traditionally associated with graffiti or street art (mobile digital cameras and social media) are argued below to be pivotal to its reframing and current embrace by property developers and municipal officials. By leveraging the communicative capacities of ubiquitously connected mobile devices and their ability to capture and disseminate digital photographs of street art, the reach of these photographs extends far beyond the limited physical confines of city streets, accessing publics accustomed to seeing vastly different photographs of Detroit. It is these digital and eminently social photographs, so often neglected in the academic literature, that are the visio-narrative devices being used to author the next chapter of Detroit's fabled history.

\section{Detroit, Michigan: From "Paris of the West" to Post-Apocalyptic Wasteland and Back Again?}

Once referred to as the "Paris of the West" for its grand boulevards, architectural splendors, cultural attractions, and geometric street plan, Detroit has long occupied a curious, if fecund, position in the collective imaginary of persons interested in the life cycles of urban space. There is of course good reason for this. Perhaps more than any other city in the twentieth or twentyfirst centuries, Detroit has experienced the wax and wane of opulence and desperation. The city's industrial past is well known and regarded - its residents infamous for having worked on the first assembly line, churning out automobiles and the accompanying pay packets responsible for driving the golden age of the Industrial Revolution. Known as the "Arsenal of Democracy" for its role in supplying Allied Forces with vehicles and munitions in the Second World War, Detroit's industrial past (and present) is emblazoned prominently on nearly every surface of the city.

Equally as infamous are the widespread social, cultural, racial, and economic convulsions that culminated in the 1967 riots. The five-day riot resulted in more than 7,000 arrests, forty-three dead, and between $\$ 40$ and $\$ 80$ million in property damage. While far too complex to do justice to here, the riots in 1967 were part of a wave of civil unrest in major US cities rooted in a much longer history of social inequality and injustice for marginal populations, particularly African Americans. The riots are also often identified as the tipping point for the so-called "white flight" of urban populations and their tax dollars to the suburbs. This term masks and distorts the complexity of the oftracist underpinnings of real-estate markets and lenders responsible for underwriting their creation and protection. ${ }^{3}$ When the flight of a large and affluent portion of the city's tax base is considered alongside 1) advancements in manufacturing technologies resulting in the loss of well-paid employment for industrial workers; 2) alterations in transportation facilitating the globalized production, distribution, and consumption of commodities; 3 ) international trade agreements that have led to the "discovery" of cheap, precarious, and non-unionized labor markets in other jurisdictions of the world with weak 


\section{Amps}

or absent environmental and/or worker protections; and 4) a long history of municipal corruption, ${ }^{4}$ Detroit's fate was sealed by a collusion of factors, not all avoidable, but most all-too-unfortunate for its residents.

Today, Detroit's grand boulevards are shells of their former selves, their vacant and poorly boarded-up architectural delights looted and scavenged by citizens seeking to scrap the smallest amount of copper or aluminum. ${ }^{5}$ In 2015, citing its high rate of violent crime, Forbes magazine named Detroit the most dangerous city in the United States for the fifth year in a row. ${ }^{6}$ Ironically, one of the biggest problems facing Detroit at present is not growth, per se, but how to become much, much smaller. The United States Census Bureau's most current data reports that in 2016, the population of Detroit was 672,795. ${ }^{7}$ At the height of the war effort between 1940 and 1950, Detroit's population reached its zenith, totaling just shy of two million residents. ${ }^{8}$ Thus, in a period of approximately seventy years, the City of Detroit hemorrhaged 63 percent of its population. As mentioned, however, the difficulty facing Detroit is not one of "regrowth," but what has been referred to by some scholars as "smart shrinkage."

Totaling just shy of $360 \mathrm{~km}^{2}$, Detroit's geographic footprint is the same as that of San Francisco, Boston, and Manhattan Island combined. However, whereas Detroit has an average of 1,892 residents per square kilometer, there is an average of 10,292 residents per square kilometer in the combined areas of San Francisco, Boston, and Manhattan. ${ }^{10}$ Detroit thus has infrastructural and service demands that other jurisdictions do not. Meeting these demands has proven a Sisyphean task, made all the more difficult by Detroit being the largest city in the history of the United States of America to declare bankruptcy in 2013.

Detroit's bankruptcy prompted the imposition of fiscal restrictions that saw the State of Michigan appoint an unelected emergency manager, Kevyn Orr, to lead the "recovery." One of the approved strategies of dealing with the financial burdens of the city was to reduce its infrastructural and service requirements by demolishing large swaths of the city under the auspices of "blight removal." According to the Detroit Blight Removal Task Force (BRTF), convened in September 2013 by the Obama Administration to "remove every blighted structure and clear every blighted vacant lot in the City of Detroit as quickly as possible," there are 84,641 blighted structures within the city limits, of which more than 40,000 are set for demolition. ${ }^{11}$ One of the three people who chairs the BRTF is Detroit-native Dan Gilbert, multibillionaire owner of Quicken Loans, the largest online mortgage lender in the United States and subsidiary of Rock Ventures. When combined with the imposed decrease in pension commitments to retired municipal workers and a number of other forced austerity measures, the planned demolition of homes will have the impact, city planners hope, of shrinking the cost of providing water, electricity, garbage disposal, snow removal, street lighting, police and fire protection, etc., to citizens. In actuality, the renewal of "Detroit" is, then, being concentrated on the rejuvenation of 18.5 of its more than $359 \mathrm{~km}^{2} .{ }^{12}$ 


\section{Amps}

The basic idea is to lure businesses, consumers, suburbanites, and what planners refer to as the "brainforce" back into the CBD, along with their consumption and tax dollars, so as to jumpstart further renewal efforts. ${ }^{13}$ One of the largest potential beneficiaries of the plan to concentrate renewal efforts on the CBD is also one of the individuals responsible for spearheading the identification and demolition of blighted structures around the sprawling city in the first place, BRTF Co-Chair Dan Gilbert. Gilbert partially funded and staffed the Motor City Mapping effort responsible for identifying all of Detroit's blighted structures. According to his biography on the Detroit Blight Removal Task Force's webpage, "today, more than 15,000 Rock Ventures team members work in downtown Detroit. Rock Ventures has invested more than $\$ 2.2$ billion to purchase and renovate 95-plus properties in downtown Detroit totaling more than 15 million $\mathrm{ft}^{2} . " 14$

As should be expected, there are comprehensive and detailed plans in place to revitalize Detroit's CBD that offer a wealth of information regarding the strategies and tactics thought needed to jump-start Detroit. Of particular note is Detroit Future City (2012), a 364-page document produced by the city's long-term planning department in conjunction with over ninety-three private, public, and corporate stakeholders that provides a neighborhoodby-neighborhood analysis of the CBD and its adjacent areas. ${ }^{15}$ Additionally, Opportunity Detroit, a private organization dedicated to rebranding Detroit (founded and funded by Gilbert) has published two planning documents: A Plan For Our Time (2013) and A Placemaking Framework For Downtown Detroit (2013). ${ }^{16}$ Especially notable for the purposes of this paper is the prominence of place given to street art in the plans to resuscitate Detroit. While a relatively small element in the overall strategy to rejuvenate Detroit, the fact that street art features at all is important and noteworthy.

\section{Urban Planning and Legal Street Art in the Post-Fordist Motor City}

One of the prioritized citywide strategies identified by the municipality in the Detroit Future City (2012) report is to "support neighborhood-based public art." ${ }^{17}$ More specifically, the Eastern Market neighborhood of Detroit, home to one of the oldest fruit and produce markets in the United States, is categorized as an "Urban Live+Make Neighborhood." According to the report's description, these neighborhoods are former industrial locations where land and buildings are plentiful, but remain unused. In these areas, three of the prioritized revitalization strategies are to 1) "promote arts and events spaces and landscapes," citing the commercial art fair, Art Basel Miami Beach, as a successful precedent and example, 2) "identify and organize arts or gallery districts," and 3) "curate and fund the creation of public art," citing Detroit's own Lincoln Street Art Park as well as the Wynwood Arts District of Miami. ${ }^{18}$ It merits emphasis that, while they are distinct and unique unto themselves, the Lincoln Street Art Park and the Wynwood Arts District of Miami are both replete with sanctioned works of street art. 


\section{Amps}

While Detroit is particularly significant because of its history and the concentration and scale of commissioned street art in the CBD, it should be noted that legal and commissioned street art features prominently in an evergrowing number of urban centers around the world. These public street art projects are most often organized under the auspices of a street art "festival," of which Detroit's Murals in the Market (MITM) is an archetype. More detail regarding MITM is provided below. For now, it suffices to emphasize the growing trend of incorporating street art forms into underused urban space.

The Detroit Future City document makes manifest the importance of street art to its authors. Beneath a diagrammatic representation of "Urban Live+Make" neighborhoods that includes numerous instances of large-scale murals representative of street art, the authors claim there needs to be "ample opportunity to imagine, invent and create new forms of industry and art," continuing, "incentive packages, including development of support networks and start-up funding/financing, should be developed to lure artists, small businesses and entrepreneurs to the district. Regulatory frameworks should be put in place to allow a wide range of uses while still protecting public health, safety, and wellbeing." 19 This statement in conjunction with the diagrammatic presentation of what this kind of neighborhood might look like, as well as the observable outcomes of these claims in the CBD, makes clear that "street art" is integral to Detroit's urban renewal strategy.

In addition to the Detroit Future City document, Rock Ventures, the parent company for all of Gilbert's holdings, partnered with The City of Detroit, The Detroit Economic Growth Corporation, General Motors, and Blue Cross/ Blue Shield (among other large and small stakeholders), on two planning documents that offer further insight into the strategic planning behind, and future vision for, Detroit's CBD. A Plan For Our Time and A Placemaking Vision for Downtown Detroit are consequential documents for many reasons ${ }^{20}$ Their avowed emphasis on the fundamental need to alter existing public perceptions of Detroit, however, make them ever more so for present purposes. For instance, in A Plan For Our Time, the authors state, "reality, of course, is very important. However, perception - and perhaps more to the point, an understanding of existing perceptions together with conscious acts taken to change them in support of the vision - is exceedingly important." ${ }^{21}$ Later on in the document, they lay out their plans in more detail: "consistent with other district identity programs, art ... will be integrated throughout the streetscape ... building facades and at grade level." 22 The incorporation of "street art" throughout the CBD, then, is a concerted attempt to alter, not only the perception of individuals living, working, and playing therein, but as will be addressed shortly, those who might one day want to live, work, or play therein. More so than any other aesthetic element of public urban space, legal and sanctioned street art has proven to be the most influential ingredient in the attempts at altering existing perceptions of Detroit.

When the prominence of space and place given to legal and sanctioned street art is considered, its role in changing existing perceptions of the CBD 


\section{Amps}

is clear. In September of 2015, 1xRun and Inner State, an urban fine art print shop and gallery respectively, organized Murals in the Market (MITM). Over forty-five local and internationally recognized artists were invited to paint large-scale murals in the avowed Urban Live+Make Eastern Market District. MITM was sponsored by a handful of corporate entities and drew over 45,000 individuals into the Eastern Market district over a period of two weeks. It was a resounding success, elevating Detroit in status "to one of the world's street art capitals." 23 One of these corporate sponsors was a casino located in the CBD and owned by Gilbert. In 2016, MITM was sponsored by Gilbert's Quicken Loans alongside a number of others that include the Knight Foundation, Behr Paints, and Faygo. The success of this festival, however, only hints at the amount of sanctioned street art found in the City of Detroit's CBD.

Gilbert's Rock Ventures owns The Madison Theater Building designed by C. Howard Crane in 1917, now referred to as the M@dison Building in service of its own rebranding strategy. The theater portion of this historic building fell victim to razing, and in its place is a parking lot with views of a six-story, 10,000 $\mathrm{ft}^{2}$ mural by street artist HENSE commissioned by Gilbert's Bedrock Real Estate Services in consultation with the Library Street Collective - an art gallery housed in another of Gilbert's buildings that describes itself as a "cutting edge modern and contemporary fine art [gallery] with a primary focus on artists who have developed their skills and visual art in public spaces." 24

Bedrock Real Estate and the Library Street Collective are also responsible for commissioning and organizing Shepard Fairey's and How \& Nosm's murals, each measuring roughly $11,000 \mathrm{ft}^{2}$ on the Compuware Building. ${ }^{25}$ Adjacent to the Compuware Building is a parking structure owned by Gilbert called the "Z Lot" that implores motorists to "Park in the Art." Each floor of the dual-tower, ten-story parking structure's interior walls were handed over to twenty-seven different street artists from around the world to legally "decorate" with their art. On street level, running beneath the Z Lot's dualtowers is The Belt. The Belt is a culturally redefined alleyway that boasts work by internationally recognized graffiti and street artists Futura, Fairey, Vhils, Cleon Peterson, HUSH, Revok, Hoxxoh, and Tristan Eaton among others.

In November 2016, street artist Swoon held a solo exhibition at the Library Street Collective and created two different pieces of "street art" for Detroit. The first is a paste-up created on the ground floor façade of what is now known as the Ally Detroit Center, formerly known as Detroit Center One and designed by John Burgee and Philip Johnson in 1991. The second is another paste-up located in the Jefferson-Chalmers area of East Detroit, a neighborhood named in the Detroit Future City: 2014 Year End Report as one "where the arts and green infrastructure combine to express unique community visions." 26

The sheer concentration and square footage of wall space dedicated to commissioned street art in the $\mathrm{CBD}$, and the fact that the $\mathrm{CBD}$ is the nucleus 


\section{Amps}

around which all of Detroit's revitalization revolves, is telling of its significance to planners. When regarded as a whole, the aforementioned pieces are overt attempts to re-image Detroit and alter the perception of the city in the mind's eye of its current residents, future citizens, potential tourists, prospective investors, the media writ large, and investment capital. ${ }^{27}$

\section{(II)Legal (Un)Sanctioned "Street Art"}

Detailing three separate, yet related events, all occurring within a few miles of each other will assist in better appreciating the prominent, yet paradoxical place of graffiti, street art, and legal street art in the fledgling revitalization of the "Motor City." 28 To begin with, on June 22, 2014, three teenage girls from Grosse Pointe Woods, a well-heeled (mostly white) suburb east of Detroit, spray-painted obscenities on the wall of one of Gilbert's high-rise office towers in the downtown core. Upon receiving evidence of the crime, Gilbert sent an email with attached surveillance photographs of the perpetrators to his 12,500 Detroit employees. Recognizing the power and reach of social media, Gilbert asked his employees to post the pictures and video to their respective social media accounts in the hope of identifying the vandals. As recompense, Gilbert offered to cover the costs of painting the entire interior and exterior of the informant's home if their tip led to arrests. ${ }^{29}$ The accused were quickly identified, eventually charged and subsequently found guilty of malicious destruction of a building, receiving a sentence of sixty hours of community service each. ${ }^{30}$

Nearly a year after this event, on May 22, 2015, world-renowned "street artist" Shepard Fairey, completed his largest artwork to date on the northwest wall of Gilbert's Quicken Loans headquarters in the Compuware Building in downtown Detroit (fig. 1). This building sits directly across the street from the one vandalized by the three Grosse Pointe teens. Covering an area in excess of $11,000 \mathrm{ft}^{2}$, the artwork was commissioned by Gilbert's Bedrock Real Estate Services, Meridian Health (co-owner of the Compuware Building), and the Library Street Collective gallery. In addition to the commissioned mural, Fairey also created a number of illegal and unsanctioned paste-ups around the city (fig. 2).

These illegal and unsanctioned pastings were created during the same time frame and used the exact same materials and media as the commissioned and sanctioned ones. Instead of a paycheck, however, the unsanctioned pastings led to his arrest at the Los Angeles International Airport on July 9, 2015, where he was ordered to return to Detroit so as to be arraigned. The case against Fairey was eventually dismissed the following year. At the time of writing, however, "the City of Detroit is planning its appeal to this ruling claiming that Mr. Fairey is not entitled to special treatment over ordinary citizens just because he is famous." 31

The contradictions made manifest by these three events nicely capture the paradoxical nature of "street art" at this particular historical juncture. At 


\section{Amps}

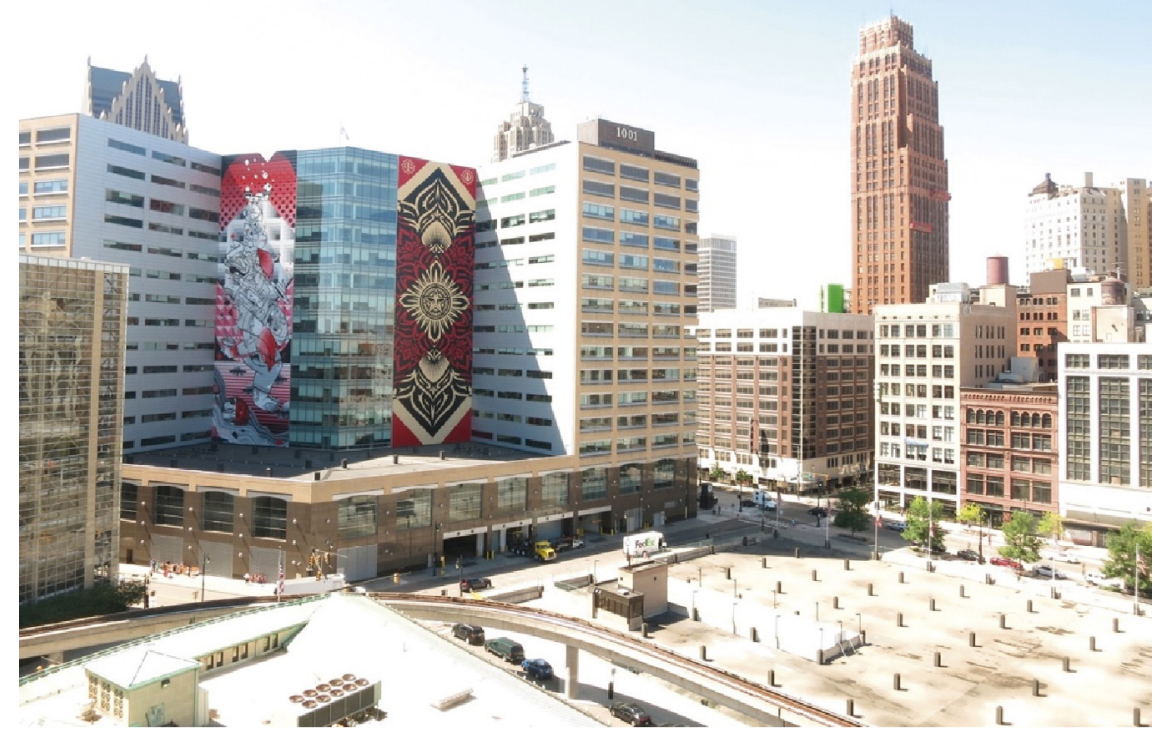

Figure 1. Murals by Shepard Fairey (right) and How \& Nosm (left). Photo by Author.

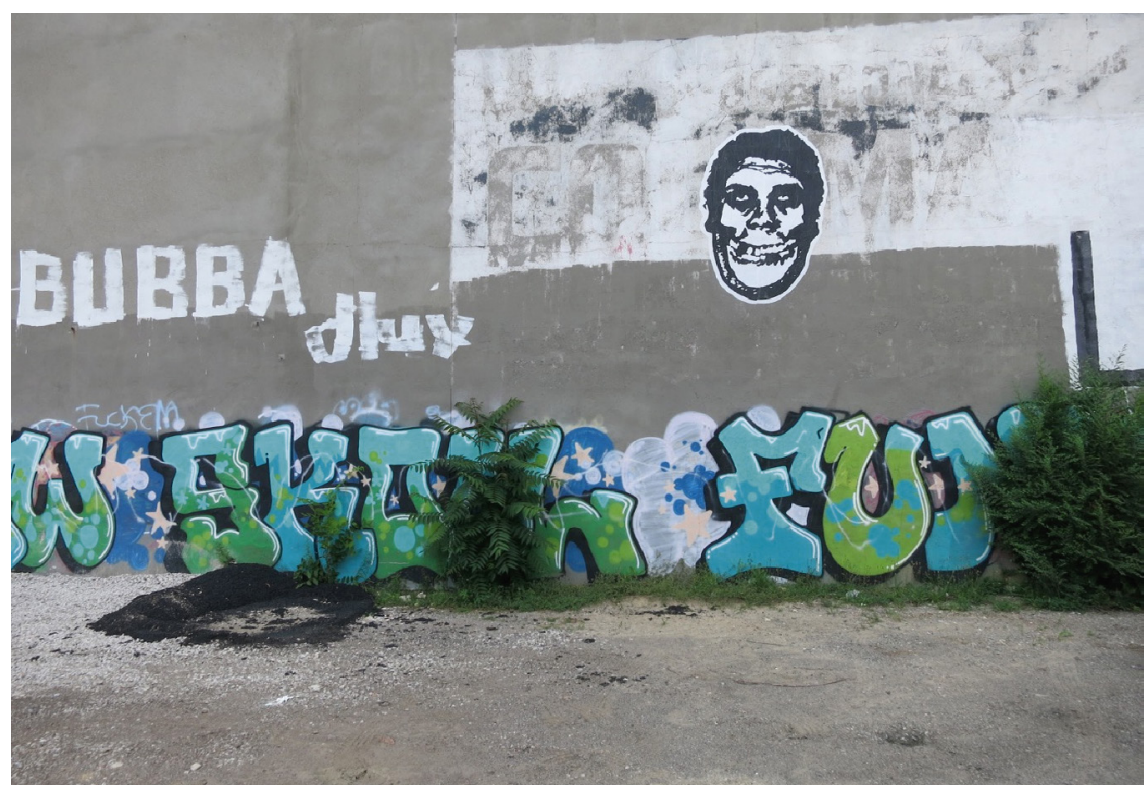

Figure 2. Unsanctioned wheat paste of "Obey Fiend Skull." Attributed to Shepard Fairey. Photo by Author. 


\section{Amps}

one and the same time, what for the time being can be called "graffiti" and "street art" are viewed as either vandalism, nuisance, and emblem of "broken windows," or highly sought-after elements in urban environments seeking to mark themselves as creative, dynamic, edgy, and hip. ${ }^{32}$ In an article exploring some of the contradictions having to do with "street art," Sarah Banet-Weiser notes:

In the twenty-first century, the commercial potential of the 'creative city' has displaced the broken windows theory and reversed the potential role of such 'nuisance'. Through the emergence of public-private partnerships within cities ... the 'graffiti problem' became, at least for some marketers, a way to harness 'street' creativity ... . The aesthetic of street art ... is now used in the image marketing of cities. ${ }^{33}$

If the international profusion of legal, municipally sanctioned and corporately sponsored street art festivals is any indication, then cities and locales as diverse as Montreal, Toronto, Coney Island, Miami, Bogota, Buenos Aires, Puerto Rico, London, Paris, Berlin, Cape Town, Taiwan, Tokyo, Melbourne, Detroit, etc., are all trying to capitalize on the allure of large-format, sanctioned street art. As the aforementioned three instances from Detroit make clear, however, the sanctioned and legal iterations of this art form, while stylistically similar, are regarded in polar fashion to their unsanctioned and illegal variants.

The allure and current acceptance of street art can be traced to its early history of furtive illegality. According to, Banet-Weiser, "this earlier demonization of graffiti proved essential for [street art's] legitimation as an urban creative practice. What better proof of the 'authenticity' of graffiti, after all, than its illegality?" ${ }^{4}$ In stark contrast to the millions of dollars of municipal monies spent waging "wars" on graffiti and illegal street art, artists are now commissioned to produce work under their given name, often with direct links to their social media accounts (see fig. 3, for example), in the full light of day, with municipal sanction, corporate sponsorship, and payment for their work. Like touring pop stars, these "street artists" are whisked around the world from one festival to the next to produce work that looks similar to its illegal predecessor, but is fully sanctioned, paid for and supported by publicprivate partnerships.

What requires accentuation is the fact that the similarities in media used to create illegal and legal graffiti as well as legal and illegal street art conceal fundamental differences in their underlying politics, power relationships, economic incentives, and communicative intentions. In fact, the kind of "street art" produced by named artists and in the full light of day actually disqualifies it from being referred to as such according to Nicholas Riggle (2010). Riggle argues that in order for street art to be regarded as such, among other things, it must have an explicit commitment to ephemerality and must use the "street" as a specific artistic resource. In both cases, much of the sanctioned and legal 


\section{Amps}

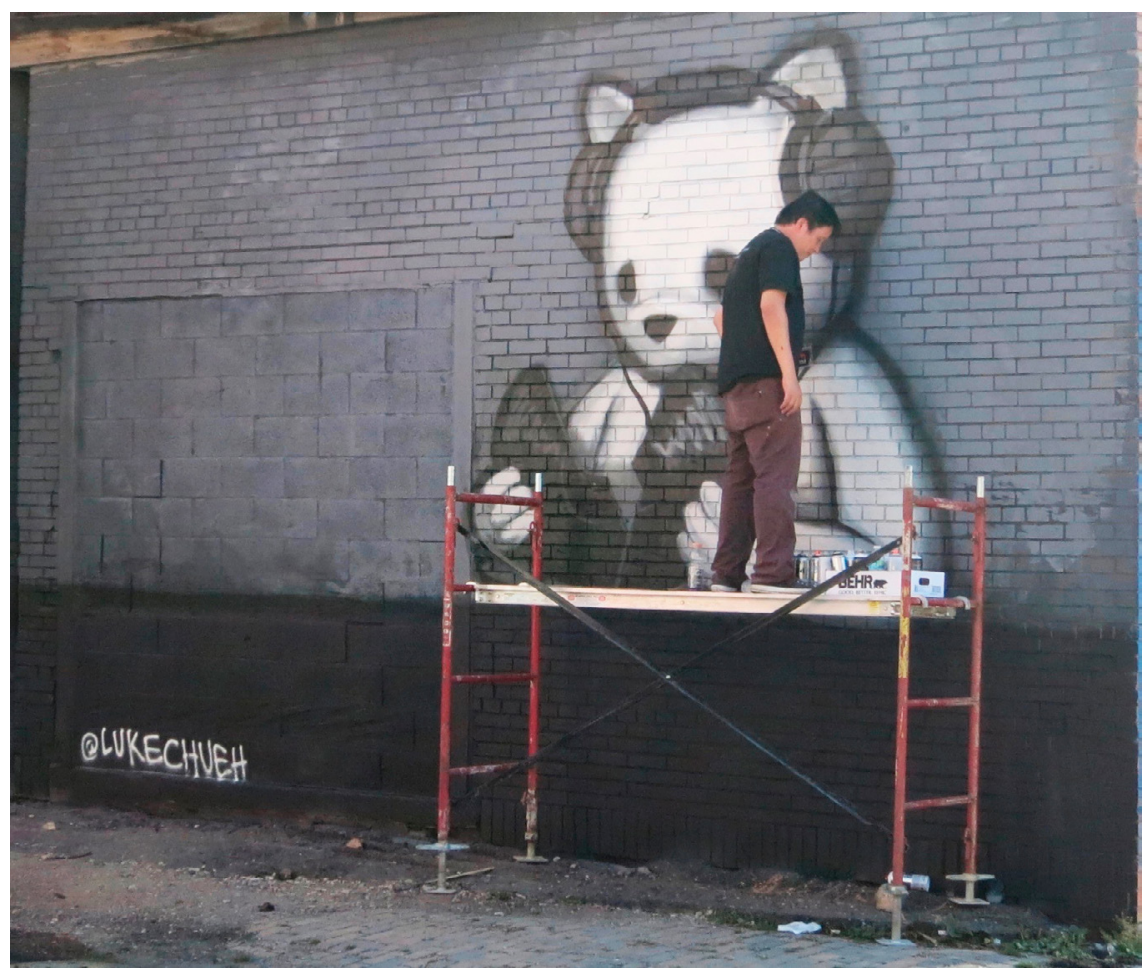

Figure 3. Luke Chueh, Mural in progress, Detroit, 2015. Note the Instagram handle in lower left corner of the mural. Photo by Author.

street art being produced today has neither a commitment to ephemerality, nor does it use the street as a specific artistic resource.

In other words and to a passerby, the illegal and legal appear very much the same. However, when their surface veneer is scratched ever so slightly, important differences are identifiable and brought to the fore. In sum, the kind of street art allowed to exist and persist in the areas of the city identified by planners and developers as worthy of saving was selected, commissioned, sanctioned, and paid for by some combination of municipal officials, property developers, and commercial sponsorship. This genus of "street art" deceptively connotes the unbridled creativity of its illegal variant, all the while availing itself of the control demanded by powerful private and municipal power and interests. As the coincident embrace and repudiation of Fairey's work in Detroit indicates, that which refuses these controls is regarded as an abject contributor to the blighted nature of the city. This kind of "street art" is therefore subject to immediate removal or destruction, its creators pursued with verve by law enforcement and/or private interests. ${ }^{35}$ 


\section{Amps}

\section{Digital-Social Photography's Function in Altering Public Perceptions and Urban Space}

Long before wealthy patrons, property developers, and municipal officials deemed street art a worthwhile investment, photographs of illicit works of street art were created and shared on niche blogs and photo-sharing social networks. ${ }^{36}$ The visitors and contributors to these blogs and networks appreciated the talent, politics, and/or courage of street artists, as well as the mystique nurtured by the precarious nature of the art form. Due to the fact that many works of street art were destroyed because of their illegality and the threat they purportedly posed to the moral order of their host communities, ${ }^{37}$ photographing works of street art left susceptible to the vagaries of street life became one of the most important means of archiving these ephemeral works. Importantly, the reach and popularity of these digital photographic reproductions via new media technologies and social media networks played a large and important part in the shift from illegal and unsanctioned art form to legitimate, lucrative, and institutionalized art form.

Naming the exact date this shift from illegal blight to sanctioned art form occurred is less important than identifying and explaining the technological catalysts responsible for it. In the interests of historical accuracy, however, the mainstreaming of street art took place in and around 2010. It was in 2010, for example, that Banksy's Oscar-nominated documentary about the clandestine history of street art, Exit Through the Gift Shop, was released, and that the street art "festival" became much more popular, with Pow! Wow! holding its inaugural meeting in Hong Kong, and Living Walls its first in Atlanta. Importantly, it was also around this time that the mobile smartphone, outfitted with high-quality digital camera, ubiquitously connected to social media platforms, and in the pockets of media-savvy individuals adept at generating and sharing all manner of digital content broadened the reach and appeal of the art form far beyond its once sub-cultural confines. It is to the unacknowledged importance of these technological advancements in the history of street art's continuing metamorphosis that we now turn our focus.

Coining the term "Digital-Social Photography" provides for a more refined appreciation of recent shifts in photographic practice brought on by the aforementioned technological advances in hardware and software and their concomitant social/behavioral influence. The term designates a shift in emphasis between our analog past and digital present so as to underscore the fact that photographs are now created with the premeditated intention of their being shared widely on social media platforms. Unlike eras past, then, prior to the photograph being made, the intentions of the photographer are often that the photograph be immediately distributed and redistributed beyond his/her immediate circle of influence to a much broader audience. The potential scope of this presumed, yet unquantifiable audience, influences the type and kind of photographs that are created. Amidst the deluge of images, however, certain digital-social photographs rise above the visual clatter and 


\section{Amps}

distinguish themselves from the clutter. Though a sustained theoretical reflection on the auratic energy emitted by (or "cultural capital" conferred upon) digital-social photographs of street art is beyond the scope of this paper, briefly emphasizing that photographs of legal street art trade on the feigned authenticity connoted by the false association with transgressive illegality and simulated ephemerality is appropriate. ${ }^{38}$ In sum, digital-social photography has proven exceptionally influential in popularizing and legitimizing street art far beyond its historical niche audience.

From the perspective of the artists themselves, the act of taking and sharing a picture of one's artwork allows for the work that is determinately locked in situ to "travel" far beyond its resolute geography. The resolute ties to space and place endow photographs of street art with a particularly seductive valence. A few quantitative measures will help make explicit the online reach of some "street artists" when compared to other public artists and figures.

The graph in Figure 4 shows the number of "followers" of the official accounts of street artists, well-known artists, and politicians on Instagram, the largest photo-sharing application in the world. These three groups were chosen for their perceived public profiles and in an attempt to emphasize the appeal of street artists to digital-social photographers when compared to other prominent artists and politicians.

\section{Prominent Street Artists, Artists and Public Figures With Respect to Instagram Followers (as of 28 November, 2016)}

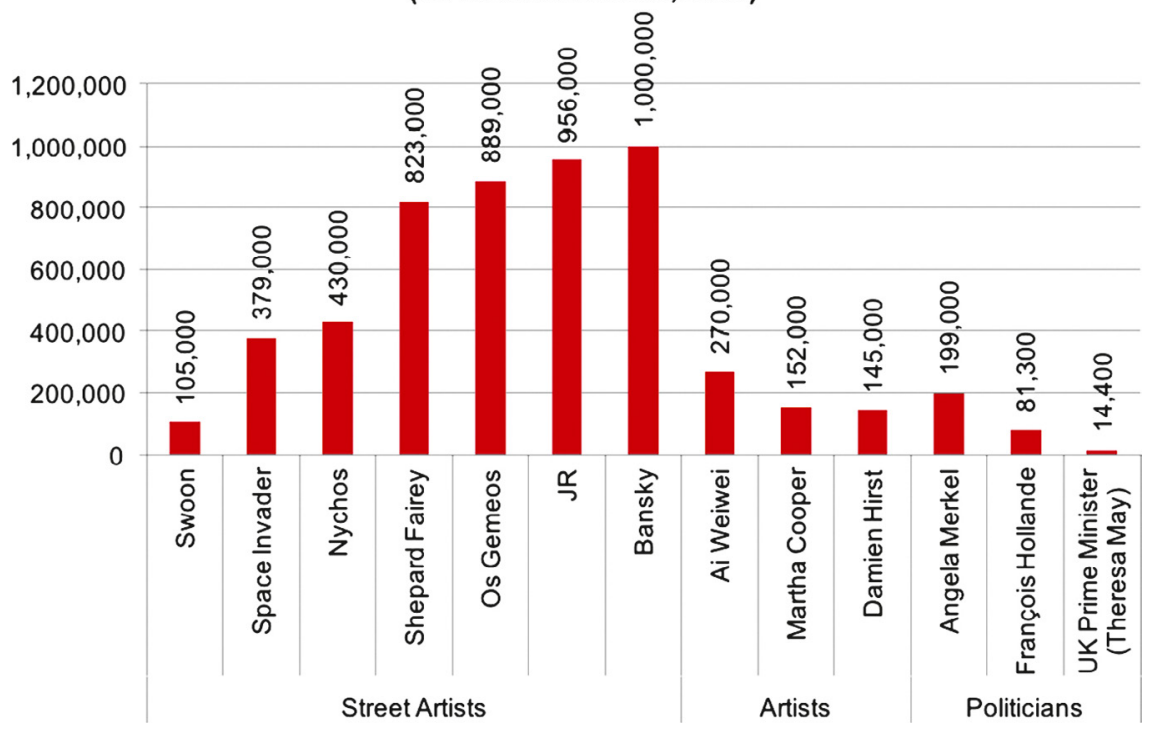

Figure 4. Prominent street artists, artists and public figures with respect to Instagram followers. ${ }^{39}$ 


\section{Amps}

As becomes eminently clear when the privileged place granted to sanctioned street art in Detroit is considered, this kind of "cultural capital" and its global currency is not lost on any of the stakeholders looking to revivify the troubled Motor City. While direct statements regarding the importance of commissioned street art in the revitalization of Detroit are non-existent, there is some signage that accompanies these works from which much can be gleaned. The Artistic Mission statement affixed to both entrances of Gilbert's $Z$ Lot, for instance, makes clear the importance of street art in the eyes of the man responsible for what New York Times journalist David Segal described as "one of the most ambitious privately financed urban reclamation projects in American history." ${ }^{40}$ Echoing the importance of altering the perception of Detroit alluded to above (see note 21), the Artistic Mission statement reads:

The positive experiences shared here are part of a new narrative and conversation that is beginning to take root. Artists, with their ability to share their work through social media - with a global population of friends and peers - have become modern versions of artistic town criers: telling new and different tales of our city.(..) When art is injected into the urban architectural environment, the structures become more than static monuments to mankind's [sic] ingenuity; they become living breathing messages of our passion. Through art's timeless witness, messages of wonder and hope can be sent out to present and future citizens of our city. ${ }^{41}$

Despite its awkward poeticism, the Artistic Mission statement makes explicit the importance of "street art" in altering perceptions and authoring a new narrative for the city of Detroit. It also does something that much of the scholarship on the relationship between street art and urban revitalization fails to do ${ }^{42}$ and that is to highlight the communicative affordances of digital photography and social media in their capacity to popularize and lend cultural currency to commissioned street art.

Regarding Detroit in particular, the city has for decades been haunted by images of its dramatic demise and decay, and is responsible for inspiring an entire genre of photography known in the colloquial as "ruin-porn." Replacing these images of desolation with those that cast Detroit in a more favorable light is of the utmost importance. Commissioned street art and its resultant digital-social photographs, then, respond to the common perception of Detroit as decayed wasteland. These works of art and more importantly to the present argument, their socially mediated after-images are therefore strategic attempts to visually alter perceptions and reshape the way Detroit is collectively regarded in the mind's eye of a now global audience of onlookers.

While a handful of scholars point to street art's vibrancy and dynamism as one of the primary aesthetic drivers drawing the "creative class" to "creative cities," ${ }^{43}$ this perspective is far too general and only partially correct in that it does not distinguish between the legal and illegal variants of the art form, nor does it acknowledge in any which way the importance of the digital-social 


\section{Amps}

photographs of the artworks. There is an important and all too significant difference between the legal and the illegal, the artwork in situ and the digitalsocial photographs thereof. These fundamental differences are, however, often elided when street art is regarded in the academic literature. The two questions that should preface any scholarly investigation of street art are, therefore, 1) is the author examining and referring to illegal and unsanctioned artwork or artwork of the legal and municipally sanctioned kind? and 2) is the author analysing an original artwork in situ or a socially mediated photographic representation thereof? The specific media and (il)legality of the piece matters very much to the accuracy of analysis undertaken and the conclusions derived therefrom. Worth emphasizing is that while the street artwork in situ is a necessary precursor, its exposure is limited. Thus, the digital-social nature of the photographs derived from it are much more important to engendering the kind of cultural capital, viral curiosity, intrigue, enthusiasm, "hype," or "buzz" required to author new perceptions and narratives of struggling urban spaces like Detroit. ${ }^{44}$

\section{Conclusion: Re-Picturing the Perception of a Post-Fordist Motor City?}

Legal, sanctioned, commissioned, and socially mediated street art is one of the most prominent and aesthetically influential pillars of Detroit's fledgling rejuvenation. Imposing concrete "canvases" of enormous proportion are liberally dappled throughout the CBD, altering the way the city looks and is hence pictured. As the mission statement that accompanies the list of artists featured in the $\mathrm{Z}$ Lot intonates, these works speak to a "new narrative and conversation" that "is beginning to take root" in the Motor City. This narrative and conversation, however, is directed at a much larger and more geographically dispersed group of individuals than those residents whose pensions were slashed, tax dollars embezzled, water service shut off, and neighborhoods razed by arsonists or blight removers.

If successful, this paper has highlighted some of the historical, legal, and artistic antecedents to the contemporary moment that sees commissioned street art playing the role of "artistic town crier" to a global village of individuals whose ideas and thoughts of Detroit were once dominated by photographs of ruin, violence, and decay. Redrafting the visual narrative and common perception of Detroit engendered over years of exposure to photographs of post-apocalyptic ruin is no small task. Repopulating this same collective imaginary with a sampling of images that connote vibrancy, creativity, and life, rather than destruction and decay, is even more difficult, if extremely important, to those who stand to benefit from this renarrativization. Remembering that the public-private partnership responsible for drafting the plans guiding Detroit's rejuvenation claim that "reality, of course, is very important. However, perception - and perhaps more to the point, an understanding of existing perceptions together with conscious acts taken to 


\section{Amps}

change them in support of the vision - is exceedingly important ${ }^{45}$ The task of swapping images of ruin, decay, and post-apocalyptic demise with those indexical of creativity, renewal, and regeneration explains why such awesome expanses of "public space" are dedicated to sanctioned street art in the CBD of Detroit, Michigan. If Detroit is to continue to attract the capital required to rebuild itself from these perceptual and narrativized ashes, the stories being told within and beyond it must change in tandem. Commissioned street art and its associated digital-social photographs are "exceedingly important" to the narrative/perceptual reboot planners deem requisite to the cty's revival.

\section{Notes}

1 Jennifer Bain, "Detroit is America's Great Comeback Story," Toronto Star, September 10, 2016, accessed July 21, 2017. https://www.thestar.com/life/ trave1/2016/09/10/detroit-is-americas-great-comeback-story.html.

2 Detroit Works Project, Detroit Future City: 2012 Detroit Strategic Framework Plan (Detroit: Inland Press, 2012), 237; Opportunity Detroit, A Plan For Our Time (Spring-Summer 2013), accessed July 21, 2017. http://opportunitydetroit. com/wp-content/themes/Opportunity_Detroit/assets/APlanforOurTime-Sm2.pdf; Opportunity Detroit, A Placemaking Vision for Downtown Detroit (SpringSummer 2013), accessed July 21, 2017. http://opportunitydetroit.com/wp-content/ themes/Opportunity_Detroit/assets/PlacemakingBook-PDFSm.pdf.

3 The multi-faceted story regarding the social, political, institutional and economic racism endemic to Detroit's decline begins much earlier, extends much later, and plunges much deeper than the riots of 1967 could ever encapsulate. This is a heinous and racist story that merits much more engaged scrutiny than an article on "street art" could aspire to provide. For a more elaborate history recounted by an academic and resident of Detroit that focuses on the role of images therein, see Dora Apel, Beautiful Terrible Ruins: Detroit and the Anxiety of Decline (New Brunswick: Rutgers University Press, 2015), 96-100.

4 Detroit was the largest city in the history of the United States to declare bankruptcy in July 2013. The story of Detroit's financial insolvency is a sordid tale of gross financial mismanagement, cronyism, and blatant criminality. Two examples are illustrative of much broader patterns. First, Kwame Kilpatrick, Detroit's 72nd mayor, was elected into power on January 1, 2002. After six-anda-half years at the helm of Detroit and on the eve of the worst global financial crisis since the Great Depression, on September 18, 2008, he resigned his office under billowing clouds of suspicion regarding a long list of criminal allegations including bribery, contract rigging, assaulting a police officer, tax evasion, mail fraud, and criminal corruption. Kilpatrick was eventually found guilty of thirteen offences and "sentenced to 28 years in prison for running a criminal racket out of City Hall, one of the longest corruption sentences in U.S. history." For more details, see Robert Snell, "Kilpatrick Likely to Appeal to U.S. Supreme Court," Detroit News, October 22, 2015, http://www.detroitnews.com/story/news/local/ detroit-city/2015/10/22/kilpatrick-loses-another-appeal-bid/74389488. Second, on 


\section{Amps}

September 9, 2016, the 13th Detroit Public School Principal was sentenced to jail for his part in a \$2.7 million dollar kickback scandal (see Tresa Baldas and Ann Zaniewski, "Judge Locks Up 4 More Detroit Principals for Robbing Students," Detroit Free Press, September 9, 2016, accessed July 21, 2017. http://www. freep.com/story/news/local/michigan/detroit/2016/09/08/judge-locks-up-4-moreprincipals-robbing-students-they-deserve-better/90090762/). The public-school system in Detroit is beset with financial difficulties with Time magazine reporting, "last year, not a single Detroit public school complied with the city's public health and safety codes" (see Josh Sanburn, "Inside Detroit's Radical Experiment to Save Its Public Schools,” Time, September 6, 2016, accessed July 21, 2017, http://time. com/4390000/detroit-public-schools-charters-debt/).

5 See Apel, Beautiful Terrible Ruins, 12-26.

6 Daniel Fisher, “America's Most Dangerous Cities," Forbes, October 29, 2015, accessed July 21, 2017, http://www.forbes.com/sites/danielfisher/2015/10/29/ americas-most-dangerous-cities-detroit-cant-shake-no-1-spot/\#a902b2412c8f.

7 United States Government Census Bureau, "Quick Facts Detroit," 1 July 2016 https://www.census.gov/quickfacts/fact/table/detroitcitymichigan/PST045216.

8 The exact figure was $1,849,568$ according to South East Michigan Council of Governments, Detroit Population History 1900-2000, September 7, 2015, accessed July 21, 2017, http://www.somacon.com/p469.php.

9 See, for example, Justin B. Hollander and Jeremy Németh, "The Bounds of Smart Decline: A Foundational Theory for Planning Shrinking Cities," Housing Policy Debate 21, no. 3 (2011): 349-367; James Rhodes and John Russo, "Shrinking 'Smart'?: Urban Redevelopment and Shrinkage in Youngstown, Ohio," Urban Geography 34, no. 3 (2013): 305-326; Amani R. Smathers, "Less Is Mo-town: Goals and Tools for 'Smart Shrinkage': Land Use Planning in Rust Belt Cities like Detroit" (major paper, King Scholar Program, Michigan State University College of Law, 2013).

10 Statistics sourced from US Census Bureau and New York City's Department of City Planning. See United States Government Census Bureau. "Quick Facts Detroit," July 1, 2016, https://www.census.gov/quickfacts/fact/table/detroitcitymichigan/ PST045216.html; New York City Department of City Planning, Population Estimates for New York City, July 2014, accessed July 21, 2017, http://www1. nyc.gov/assets/planning/download/pdf/data-maps/nyc-population/pop-estimatesalternative-narrative.pdf respectively.

11 The Detroit Blight Removal Task Force defines blight on their website as "property that: i) is a public nuisance, ii) is an attractive nuisance, iii) is fire damaged or otherwise dangerous, iv) has code violations posing a severe and immediate health or safety threat, v) is open to the elements and trespassing, vi)is already on Detroit's Buildings, Safety, Engineering, and Environmental Department (BSEED) Demolition list, vii) is owned or is under the control of a land bank, viii) has had the utilities, plumbing, heating or sewerage disconnected, destroyed, removed, or rendered ineffective, ix) is a tax-reverted property, $x$ ) has been vacant for five consecutive years, and not maintained to code." See Detroit Blight Removal Task Force, "FAQs," accessed December 15, 2016. http://www.timetoendblight. 


\section{Amps}

com/faq/\#3; Rose Hackman, "Detroit Demolishes Its Ruins: 'The Capitalists Will Take Care of the Rest," Guardian, September 28, 2014, http://www.theguardian. com/money/2014/sep/28/detroit-demolish-ruins-capitalists-abandoned-buildingsplan; Detroit Blight Removal Task Force; “About,” accessed December 15, 2016, http://www.timetoendblight.com/about/.

12 Hudson-Webber Foundation, the Detroit Economic Growth Corporation, the Downtown Detroit Partnership, Midtown Detroit, Inc., Invest Detroit, and Data Driven Detroit, 7.2 Sq Mi: A Report on Greater Downtown Detroit, 2nd ed. Detroit Seven Point Two, February 2015, accessed July 22, 2017, http:// detroitsevenpointtwo.com/resources/7.2SQ_MI_Book_FINAL_LoRes.pdf.

13 In an allusion to the industrial labor force of the past and telling of the fundamental changes to have taken place in the labour market not only in Detroit but globally, the literature refers to the individuals targeted to repopulate the CBD and its adjacent districts as the "brainforce." See Opportunity Detroit, A Placemaking Vision.

14 The Detroit Blight Removal Task Force, “About," accessed December 15, 2016, http://www.timetoendblight.com/about/.

15 Detroit Works Project, Detroit.

16 Opportunity Detroit, A Plan; Opportunity Detroit, A Placemaking Vision.

17 Detroit Works Project, Detroit Future City, 233.

18 The Lincoln Street Art Park (LSAP) is located in an abandoned industrial site north-west of Detroit's CBD and near the campus of Wayne State University. Organized by "Green Living Science," a group dedicated to transforming "Detroit by teaching recycling," according to the "Who We Are" section of their website (http://greenlivingscience.org/who-we-are/). Regarding the LSAP, Green Living Science explains that "[a]s new generations are attracted to these vibrant urban settings, they hope to explore and learn from their predecessors and to create new sites, reflective of their experiences. Thoughtful strategy and creative place making help guide this process of urban renewal, which results in stronger neighborhoods, tighter community bonds and a sense of ownership" (see "Lincoln Street Art Park" under the "What We Do" section: http://greenlivingscience.org/lincolnstreet-art-park/). Similarly, the Wynwood Arts District in Miami is anchored by the Wynwood Walls, a sanctioned street art district and artistic project developed by the late Tony Goldman that transformed a once derelict and violent warehouse district in Miami into one of the premier tourist destinations in the state. According to the official website, accessed July 22, 2017 (http://www.thewynwoodwalls.com/ overview), "The Wynwood Walls became a major art statement with [Goldman's] commitment to graffiti and street art, a genre that he believed was under appreciated and not respected historically ... Since its inception, the Wynwood Walls program has seen over 50 artists representing 16 countries, and have covered over $80,000 \mathrm{ft}^{2}$ of walls. They have become must see international destination, with media coverage that has included the New York Times, BBC News, Vanity Fair and Forbes, who mentioned them along with Wynwood on their list of America's hippest neighborhoods."

19 Detroit Works Project, Detroit Future City, 237. 


\section{Amps}

20 Opportunity Detroit, A Plan; Opportunity Detroit, A Placemaking Vision.

21 Author's emphasis. Opportunity Detroit, A Plan, 31.

22 Opportunity Detroit, A Plan, 76.

23 Rob Wilkes, "Murals in the Market Detroit," We Heart, October 1, 2015, accessed July 22, 2017, http://www.we-heart.com/2015/10/01/murals-in-the-market-detroit/.

24 Library Street Collective, "About," accessed December 15, 2016, http://www. lscgallery.com/about/.

25 Mark Stryker, "Shepard Fairey Finishes Huge Mural at One Campus Martius," Detroit Free Press, May 23, 2015, accessed July 22, 2017, http://www.freep.

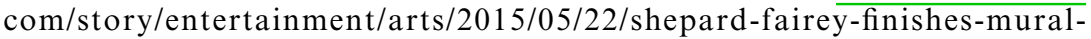
detroit/27791143/. Ironically, Fairey has been brought up on charges of property destruction and vandalism for doing the exact same thing as Gilbert commissioned him to do on the Compuware Building without permission at other locations around the city.

26 Detroit Future City Implementation Office, Detroit Future City: 2014 Year End Report, 14-15, http://detroitfuturecity.com/wp-content/uploads/2014/02/ DFC_2014YearEndReport.pdf.

27 For an excellent presentation of the importance of urban space to global capital investment, see David Harvey, The Urbanization of Capital: Studies in the History and Theory of Capitalist Urbanization (Baltimore: Johns Hopkins University Press, 1985).

28 The important historic and stylistic differences between graffiti and street art are addressed in detail on pp. 7-9

29 Email quoted in full at Lee DeVito, "Graffiti Vandals, Be Warned: Dan Gilbert is Watching You," Metro Times, June 30, 2014, accessed July 22, 2017, https://www.metrotimes.com/news-hits/archives/2014/06/30/graffiti-vandalsbe-warned-dan-gilbert-is-watching-you.

30 Gus Burns, "Three Grosse Pointe Woods Teens Get Community Service for Vandalism in Detroit," MLive, August 25, 2014, accessed July 22, 2017, www. mlive.com/news/detroit/index.ssf/2014/08/three_grosse_pointe_woods_teen.html.

31 Jim Schaefer, "Judge Tosses Case Against Street Artist Shepard Fairey; City to Appeal," Detroit Free Press, June 29, 2016, accessed July 22, 2017, http://www.freep.com/story/news/local/michigan/detroit/2016/06/29/ judge-tosses-case-against-street-artist-shepard-fairey-city-appeal/86523206/.

32 For the article that introduced the "broken windows" theory, see George Kelling and James Q. Wilson, "Broken Windows: The Police and Neighborhood Safety," The Atlantic Monthly, March 1982.

33 Sarah Banet-Weiser, "Branding Creativity: Creative Cities, Street Art, and 'Making Your Name Sing,"' in Authentic ${ }^{\mathrm{TM}}$. The Politics of Ambivalence in a Brand Culture, ed. Banet-Weiser (New York: New York University Press, 2012), 91-124.

34 See Banet-Weiser, "Branding," 104.

35 As described in Schaefer, "Judge."

36 In particular, the website ekosystem (http://home.ekosystem.org/), founded in 1999, and the Wooster Collective's blog (http://www.woostercollective.com/), founded in 2001, were early sites where fans and members of the subculture 


\section{Amps}

gathered and shared photographs. Along with speciality groups on Flickr.com, these online fora were particularly popular locales responsible for archiving, and hence in tandem, making more popular, illegal and unsanctioned street art.

37 A process known amongst artists and aficionados as "the buff."

38 The obvious allusion is to the work of Walter Benjamin and Pierre Bourdieu. See, in particular, Walter Benjamin, "The Work of Art in the Age of Mechanical Reproduction," in Illuminations: Essays and Reflections, ed. Hannah Arendt, trans. Harry Zohn (New York: Schocken, 1969) and Pierre Bourdieu, "Class Tastes and Life-Styles," in Distinction: A Social Critique of the Judgment of Taste (London: Routledge and Kegan Paul, 1984).

39 It is important to note that Banksy is without question the most "well known" street artist in the world even though his/her/their identity remains a mystery. This is due in large part to his/her/their online presence. With respect to Instagram, however, Bansky has posted a total of 34 images and does not follow anyone else on the social media service. Her/His/Their number of followers is indicative of the broad allure of "street artists" at this point in history.

40 David Segal, “A Missionary's Quest to Remake Motor City,” New York Times, April 14, 2013, http://www.nytimes.com/2013/04/14/business/dan-gilberts-questto-remake-downtown-detroit.html

41 Author's emphasis. The full Artistic Mission statement is engraved in stainless steel and posted at both entrances to the two parking structures of the Z Lot alongside work by Maya Hayuk and Logan Hicks.

42 See, for example, Alison Young, Street Art and the Public City: Law, Crime, and the Urban Imagination (New York: Routledge, 2014). Chapters 3 and 5 are of particular interest in this regard.

43 For an excellent assessment of the confluence between street art and gentrification without any discussion of digital technologies, see Rafael Schacter, "The Ugly Truth: Street Art, Graffiti and the Creative City ," Art \& the Public Sphere 3, no. 2 (2014): 161-176, doi: 10.1386/aps.3.2.161_1; Tara Foster, “The Streets Are Talking: The Aesthetics of Gentrification in Two Downriver New Orleans Neighborhoods" (Master's thesis, University of New Orleans, 2013); Rafael Shacter, "From Dissident to Decorative: Why Street Art Sold Out and Gentrified Our Cities," The Coversation, November 9, 2015, accessed July 22, 2017, https://theconversation. com/from-dissident-to-decorative-why-street-art-sold-out-and-gentrified-ourcities-46030; Cameron McAuliffe, "Graffiti or Street Art? Negotiating the Moral Geographies of the Creative City," Journal of Urban Affairs 34, no. 2 (2012): 189-206; Richard Florida, Rise of the Creative Class: Revisited (New York: Basic Books, 2012.), 183-349; Richard Florida, "Cities and the Creative Class," City and Community 2, no. 1 (2003): 3-19. For a particularly prominent example of the undifferentiated treatment of legal and illegal street art, see, in particular, BanetWeiser, "Branding."

44 For example, Shepard Fairey's Instagram account (www.instagram.com/obeygiant/) posted 27 images of his time in Detroit in 2015. In sum these images were "liked" more than 264,200 times by the followers of his account as of July 25, 2016.

45 Author's emphasis. Opportunity Detroit, A Plan, 31. 


\section{Bibliography}

Apel, Dora. Beautiful Terrible Ruins: Detroit and the Anxiety of Decline. New Brunswick: Rutgers University Press, 2015.

Austin, Dan. "The Madison Theater Building," n.d. Accessed February 16, 2016. http://historicdetroit.org/building/madison-theatre-building/.

Austin, Dan, and Sean Doerr. Lost Detroit. Gloucestershire: The History Press, 2010.

Bain, Jennifer. "Detroit is America's Great Comeback Story." Toronto Star, September 10, 2016. Accessed July 22, 2017. https://www.thestar.com/life/travel/2016/09/10/ detroit-is-americas-great-comeback-story.html.

Baldas, Tresa, and Ann Zaniewski, "Judge Locks Up 4 More Detroit Principals for Robbing Students.” Detroit Free Press, September 9 2016. Accessed July 22, 2017. http://www.freep.com/story/news/local/michigan/detroit/2016/09/08/judge-locksup-4-more-principals-robbing-students-they-deserve-better/90090762/.

Banet-Weiser, Sarah. "Convergence on the Street: Rethinking the Authentic/ Commercial Binary.” Cultural Studies 25, no. 4-5 (2011): 641-658.

Banet-Weiser, Sarah. "Branding Creativity: Creative Cities, Street Art, and 'Making Your Name Sing." In Authentic ${ }^{\mathrm{TM}}$ : The Politics of Ambivalence in a Brand Culture, edited by Banet-Weiser, 91-124. New York: New York University Press, 2012.

Barthes, Roland. Camera Lucida. New York: Hill and Wang, 1981.

Benjamin, Walter. "The Work of Art in the Age of Mechanical Reproduction." In Illuminations: Essays and Reflections, edited by Hannah Arendt, translated by Harry Zohn, 214-218. New York: Schocken, 1969.

Berger, John. Ways of Seeing. London: British Broadcasting Corporation and Penguin Books, 1972.

Berger, John. About Looking. New York: Vintage Books, 1992.

Borghini, Stefania, Luca Visconti, Laurel Anderson, and John Sherry Jr. "Symbiotic Postures of Commercial Advertising and Street Art." Journal of Advertising 39, no. 3 (2010): 113-126.

Bourdieu, Pierre. "Class Tastes and Life-Styles'. In Distinction: A Social Critique of the Judgment of Taste, 257-317. London: Routledge and Kegan Paul, 1984.

Bradley, Bill. "Detroit Blight Taskforce Must Overcome Mountains of Paperwork, Squatters and Dirt." Next City, March 17, 2015. https://nextcity.org/daily/entry/ detroit-blight-task-force-mountains-of-paperwork-squatters-dirt

Brown, Brian. "Digitized Street Art." In Media Art and the Urban Environment Engendering Public Engagement with Urban Ecology, edited by Francis Marchese, 267-284. New York: Springer International Publishing, 2015.

Burns, Gus. "Three Grosse Pointe Woods Teens Get Community Service for Vandalism in Detroit." MLive. August 25, 2014. Accessed July 22, 2017. www. mlive.com/news/detroit/index.ssf/2014/08/three_grosse_pointe_woods_teen.html.

Castleman, Craig. Getting Up: Subway Graffitti in New York. Cambridge: MIT Press, 1984.

Cooper, Martha. Hip Hop Files: Photographs 1979-1984. Berlin: From Here to Fame, 2013. 


\section{Amps}

Cooper, Martha, and Henry Chalfant. Subway Art. London: Thames and Hudson, 1984.

DeVito, Lee. "Graffiti Vandals, Be Warned: Dan Gilbert is Watching You." Metro Times. June 30, 2014. Accessed July 22, 2017. http://www.metrotimes. com/Blogs/archives/2014/06/30/graffiti-vandals-be-warned-dan-gilbert-iswatching-you.

Detroit Blight Removal Task Force. “About.” Accessed November 28, 2016. http:// www.timetoendblight.com/about/.

Detroit Blight Removal Task Force. “FAQ.” Accessed 28 November 28, 2016. http:// www.timetoendblight.com/faq/\#5.

Detroit Future City Implementation Office. Detroit Future City: 2014 Year End Report, http://detroitfuturecity.com/wp-content/uploads/2014/02/DFC_2014Year EndReport.pdf.

Detroit Historical Society. "Uprising of 1967." Accessed November 28, 2016. http:// detroithistorical.org/learn/encyclopedia-of-detroit/riots-1967.

Detroit Works Project. Detroit Future City: 2012 Detroit Strategic Framework Plan. Detroit: Inland Press, 2012. Accessed July 22, 2017. https://detroitfuturecity.com/ wp-content/uploads/2014/12/DFC_Full_2nd.pdf.

Dickens, Luke. "Placing Post-Graffiti: The Journey of the Peckham Rock." Cultural Geographies 15, no. 4 (2008): 471-496.

Fisher, Daniel. “America's Most Dangerous Cities.” Forbes. October 29, 2015. Accessed July 22, 2017. http://www.forbes.com/sites/danielfisher/2015/10/29/americas-mostdangerous-cities-detroit-cant-shake-no-1-spot/\#a902b2412c8f.

Florida, Richard. "Cities and the Creative Class." City and Community 2, no. 1 (2003): 3-19.

Florida, Richard. Rise of the Creative Class: Revisited. New York, New York: Basic Books, 2012.

Foster, Tara. "The Streets Are Talking: The Aesthetics of Gentrification in Two Downriver New Orleans Neighborhoods." Master's thesis, University of New Orleans, 2013.

Gastman, Roger, and Caleb Neelon. The History of American Graffiti. New York, New York: Harper Design, 2011.

Hackman, Rose. "Detroit Demolishes its Ruins: 'The Capitalists Will Take Care of the Rest."' Guardian, September 28, 2014. Accessed July 22, 2017. http://www.theguardian.com/money/2014/sep/28/detroit-demolish-ruinscapitalists-abandoned-buildings-plan.

Harvey, David. The Urbanization of Capital: Studies in the History and Theory of Capitalist Urbanization. Baltimore: Johns Hopkins University Press, 1985.

Hollander, Justin B., and Jeremy Németh. "The Bounds of Smart Decline: A Foundational Theory for Planning Shrinking Cities.” Housing Policy Debate 21, no. 3 (2011): 349-367.

Hudson-Webber Foundation, the Detroit Economic Growth Corporation, the Downtown Detroit Partnership, Midtown Detroit, Inc., Invest Detroit and Data Driven Detroit. 7.2 Sq Mi: A Report on Greater Downtown Detroit, 2nd ed. Detroit Seven Point Two, February 2015. Accessed July 22, 2017. http:// detroitsevenpointtwo.com/resources/7.2SQ_MI_Book_FINAL_LoRes.pdf. 
Johnson, Bobbie. "Privacy No Longer a Social Norm, Says Facebook Founder." Guardian, January 11, 2010. http://www.guardian.co.uk/technology/2010/jan/11/ facebook-privacy.

Kelling, George, and James Q. Wilson. "Broken Windows: The Police and Neighborhood Safety." Atlantic Monthly, March 1982, 29-38.

Library Street Collective. "About." Accessed 28 November 28, 2016. http://www. lscgallery.com/about/.

McAuliffe, Cameron. "Graffiti or Street Art? Negotiating the Moral Geographies of the Creative City." Journal of Urban Affairs 34, no. 2 (2012): 189-206.

Moore, Andrew, and Phillip Levine. Detroit Disassembled. Akron: Damiani/Akron Art Museum, 2010.

New York City Department of City Planning. Population Estimates for New York City. July 2014. Accessed July 22, 2017. http://www1.nyc.gov/assets/ planning/download/pdf/data-maps/nyc-population/pop-estimates-alternativenarrative.pdf.

Opportunity Detroit. A Placemaking Vision for Downtown Detroit. Spring-Summer 2013. Accessed July 22, 2017. http://opportunitydetroit.com/wp-content/themes/ Opportunity_Detroit/assets/PlacemakingBook-PDFSm.pdf.

Opportunity Detroit. A Plan For Our Time. Spring-Summer 2013. Accessed July 22, 2017. http://opportunitydetroit.com/wp-content/themes/Opportunity_Detroit/ assets/APlanforOurTime-Sm2.pdf.

Pinho, Kirk. "Gilbert Purchases 1900 Saint Antoine Building across from Stalled Detroit Jail Project.” Crain's Detroit Business, March 15, 2016. Accessed July 22, 2017. http://www.crainsdetroit.com/article/20160315/NEWS/160319915/gilbertpurchases-1900-saint-antoine-building-across-from-stalled.

Rhodes, James, and John Russo. "Shrinking 'Smart'? Urban Redevelopment and Shrinkage in Youngstown, Ohio." Urban Geography 34, no. 3 (2013), 305-326.

Riggle, Nicholas. "Street Art: The Transfiguration of the Commonplaces." The Journal of Aesthetics and Art Criticism 68, no. 3 (2010): 243-257.

Sanburn, Josh. "Inside Detroit's Radical Experiment to Save Its Public Schools," Time, September 6, 2016. Accessed July 22, 2017. http://time.com/4390000/ detroit-public-schools-charters-debt/.

Schaefer, Jim. "Judge Tosses Case Against Street Artist Shepard Fairey; City to Appeal." Detroit Free Press, June 29, 2016. Accessed July 22, 2017. http://www.freep.com/story/news/local/michigan/detroit/2016/06/29/ judge-tosses-case-against-street-artist-shepard-fairey-city-appeal/86523206/.

Segal, David. "A Missionary's Quest to Remake Motor City." New York Times, April 14, 2013. Accessed July 22, 2017. http://www.nytimes.com/2013/04/14/business/ dan-gilberts-quest-to-remake-downtown-detroit.html.

Shacter, Rafael.. "The Ugly Truth: Street Art, Graffiti and the Creative City." Art \& the Public Sphere 3, no. 2 (2014): 161-176. doi: 10.1386/aps.3.2.161_1.

Shacter, Rafael. "From Dissident to Decorative: Why Street Art Sold Out and Gentrified Our Cities." The Conversation, 9 November 2015. Accessed July 22, 2017. https://theconversation.com/from-dissident-to-decorative-why-street-artsold-out-and-gentrified-our-cities-46030. 


\section{Amps}

Silver, Tony. Style Wars. Public Art Films, 1983. 16 mm, 70 min.

Smathers, R. Amani. "Less Is Mo-town: Goals and Tools for 'Smart Shrinkage': Land Use Planning in Rust Belt Cities Like Detroit.” Major Paper, King Scholar Program, Michigan State University College of Law, Lansing, 2013. Accessed July 22, 2017. http://www.law.msu.edu/king/2012-2013/Smathers.pdf.

Snell, Robert. "Kilpatrick Likely to Appeal to U.S. Supreme Court." Detroit News, October 22, 2015. Accessed July 22, 2017. http://www.detroitnews.com/story/ news/local/detroit-city/2015/10/22/kilpatrick-loses-another-appeal-bid/74389488/.

South East Michigan Council of Governments. Detroit Population History 1900-2000. September 7, 2015. Accessed July 22, 2017. http://www.somacon.com/p469.php.

Stryker, Mark. "Shepard Fairey Finishes Huge Mural at One Campus Martius." Detroit Free Press, May 23, 2015. Accessed July 22, 2017. http://www.freep.com/story/ entertainment/arts/2015/05/22/shepard-fairey-finishes-mural-detroit/27791143/.

Thornton, Sarah. Club Cultures: Music, Media and Subcultural Capital. Revised Edition. Hoboken: Wiley, 2013.

Turkle, Sherry. "Always-on/Always-on-you: The Tethered Self." In Handbook of Mobile Communication Studies, edited by James E. Katz, 121-137. Cambridge: MIT Press, 2008.

United States Government Census Bureau. "Quick Facts: Detroit, San Francisco, Boston.” US Census Bureau, December 2, 2015. Accessed July 22, 2017. http:// www.census.gov/quickfacts/table/PST045215/00,2622000,2507000,0667000.

United States Government Census Bureau. "Quick Facts Detroit," December 2, 2015. Accessed July 22, 2017. http://quickfacts.census.gov/qfd/states/26/2622000.html.

Wilkes, Rob. "Murals in the Market Detroit." We Heart, October 1, 2015. Accessed July 22, 2017. http://www.we-heart.com/2015/10/01/murals-in-the-market-detroit/.

Young, Alison. Street Art and the Public City: Law, Crime, and the Urban Imagination. New York: Routledge, 2014. 